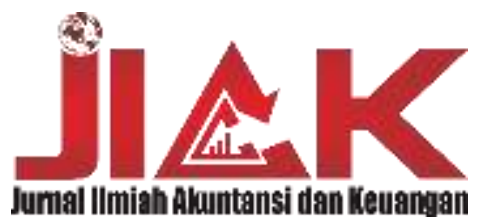

http://journal.stieputrabangsa.ac.id/index.php/jiak

ISSN: 2580-510X/ P-ISSN: 2548-9453

ARTICLE INFORMATION

Received April $17^{\text {th }} 2020$

Accepted September $22^{\text {th }} 2020$

Published January $31^{\text {st }} 2021$

DOI:

https://doi.org/10.32639/jiak. v9i2.519

\section{Analisis Rentabilitas Ekonomi Perusahaan Property and Real Estate di BEI 2016-2018}

\author{
Yuni Chikmawati ${ }^{1}$, Yuniningsih ${ }^{2}$ \\ 1,2) Universitas Pembangunan Nasional "Veteran" \\ email: yunichikma@gmail.com ${ }^{1}$
}

\begin{abstract}
ABSTRAK
Penelitian ini bertujuan untuk mengetahui apakah terdapat pengaruh antara perputaran kas, perputaran modal kerja dan perputaran total aset terhadap rentabilitas ekonomi pada perusahaan property and real estate yang terdaftar di Bursa Efek Indonesia. Sampel dipilih melalui metode purposive sampling sebanyak 46 perusahaan property and real estate yang terdaftar di Bursa Efek Indonesia periode 2016-2018. Penelitian ini menggunakan data sekunder yaitu dari laporan keuangan perusahaan. Metode analisis yang digunakan yaitu uji asumsi klasik, analisis linier berganda dan uji hipotesis. Hasil dari penelitian ini adalah secara parsial, perputaran kas berpengaruh negatif tidak signifikan terhadap rentabilitas ekonomi. Untuk perputaran modal kerja mempunyai pengaruh positif tidak signifikan terhadap rentabilitas ekonomi. Dan untuk perputaran total aset mempunyai pengaruh yang positif signifikan terhadap rentabilitas ekonomi. Sedangkan secara simultan perputaran kas, perputaran modal kerja, dan perputaran total aset berpengaruh terhadap rentabilitas ekonomi.
\end{abstract}

Kata Kunci: Perputaran Kas; Perputaran Modal Kerja; Perputaran Total Aset; Rentabilitas Ekonomi

\begin{abstract}
This study aims to determine whether there is an influence between cash turnover, working capital turnover and total asset turnover on economic rentability in property and real estate companies listed on the Indonesia Stock Exchange. Samples were selected through a purposive sampling method of 46 property and real estate companies listed on the Indonesia Stock Exchange in the 2016-2018 period. This study uses secondary data from the company's financial statements. The analytical method used is the classical assumption test, multiple linear analysis and hypothesis testing. The results of this study are partially, cash turnover has no significant negative effect on economic rentability. For working capital turnover, it has an insignificant positive effect on economic rentability. And the total assets turnover has a significant positive effect on economic rentability. Whereas simultaneous cash turnover, working capital turnover, and total asset turnover affect economic rentability.
\end{abstract}

Keywords: Cash Turnover; Working Capital Turnover; Total Asset Turnover; Economic Rentability 


\section{PENDAHULUAN}

Perkembangan sektor industri property di Indonesia dipercaya akan turut memberikan dampak besar bagi pertumbuhan ekonomi nasional. Hal ini dikarenakan sektor tersebut banyak berhubungan dengan bidangbidang lainnya. Sektor property memiliki karakter yang baik karena sektor tersebut bersifat mampu mendorong sektor lain supaya lebih berkembang lagi kedepannnya. Sektor lain yang dimaksud adalah seperti sektor industri material, sektor industri logistik, sektor industri bidang jasa, juga sektor industri keuangan dan perbankan. Pertumbuhan industri property yang cepat akan berdampak terhadap pertumbuhan ekonomi negara.

Berdasarkan survei penduduk antar sensus tahun 2015, jumlah penduduk di Indonesia diprediksi akan mengalami peningkatan pada tahun 2019 yaitu mencapai 266,91 juta jiwa. Dampak dari adanya pertumbuhan penduduk di Indonesia salah satunya adalah turut meningkatnya jumlah permintaan akan hunian. Pada tahun 2016 bank dunia juga mengeluarkan laporan bahwa kebutuhan rumah di Indonesia akan mencapai 920 ribu unit pertahun. Sedangkan angka ketersediaannya hanya mencapai 400 ribu unit per tahun. Kondisi tersebut tentunya akan berdampak pada penjualan yang semakin meningkat dan keuntungan yang diperoleh juga akan meningkat. Jika keuntungan yang didapat oleh perusahaan ini meningkat, maka nilai rentabilitas akan ikut meningkat pula. Berdasarkan fenomena tersebut, maka dapat dijadikan sebagai bahan penelitian untuk membuktikan bagaimana rentabilitas yang terjadi ketika perusahaan property sekarang sedang naik-naiknya.

Rentabilitas perusahaan diukur dengan keberhasilan perusahaan dan kemampuan perusahaan itu sendiri dalam penggunaan aktivanya secara produktif (Munawir, 2002). Dalam penelitian ini rentabilitas diukur dengan menggunakan rentabilitas ekonomi. Rentabilitas ekonomi merupakan rasio yang dapat mengukur kemampuan aktiva didalam perusahaan dalam memperoleh laba dari operasi perusahaan tersebut (Husnan \& Pudjiastuti, 2004:73).

Perputaran kas dapat menjadi faktor untuk rentabilitas ekonomi karena jika suatu perusahaan memiliki perputaran kas yang efisien maka menunjukkan bahwa perusahaan tersebut mampu memperoleh laba atau keuntungan yang efisien pula. Perputaran modal kerja menunjukkan efektivitas penggunaan seluruh harta yang dimiliki oleh perusahaan dalam menghasilkan penjualan yang nantinya akan menghasilkan laba. Sedangkan untuk Perputaran total aset jika semakin tinggi tingkat perputarannya maka perusahaan tersebut dapat mengoperasikan aktiva yang digunakan dalam menjalankan kegiatan operasionalnya dengan efisien. Tentunya hal ini akan berdampak pada hasil penjualan yang meningkat dan nantinya akan memperoleh laba.

Tabel 1. Rata-rata Rentabilitas ekonomi

\begin{tabular}{cc}
\hline Tahun & Rata-rata \\
\hline 2016 & 4,75 \\
2017 & 3,763 \\
2018 & 3,808 \\
\hline
\end{tabular}

Sumber: data diolah

Rata-rata pergerakan rentabilitas ekonomi perusahaan property and real estate dari tahun 2016 hingga 2018 mengalami fluktuasi terutama pada tahun 2017 yang rata-rata pergerakannya menurun sebesar 0,987 dari tahun sebelumnya yaitu tahun 2016. Namun pada tahun 2018 kembali meningkat sebesar 0,045 dari tahun 2017. Walaupun mengalami fluktuasi, rata-rata pergerakan rentabilitas ekonomi perusahaan property and real estate masih berada pada nilai yang positif. Dari adanya hal tersebut, maka dapat disimpulkan bahwa permasalahan dari penelitian ini adalah rentabilitas ekonomi perusahaan sub 
sektor property and real estate mengalami fluktuasi dari tahun ke tahunnya. Jika rentabilitas ekonomi perusahaan mengalami penurunan atau berfluktuasi, maka aktivitas perusahaan cenderung juga akan mengalami fluktuasi. Hal ini dikarenakan laba yang didapat oleh perusahaan juga dialokasikan untuk kegiatan operasional perusahaan tersebut.

Perputaran kas atau cash turnover ialah perbandingan dari penjualan dengan jumlah kas rata-rata yang terdapat pada suatu perusahaan. Semakin tinggi tingkat dari perputaran kas maka dapat disimpulkan bahwa semakin tinggi juga kas yang akan kembali dan akan masuk ke dalam perusahaan tersebut (Riyanto, 2011). Dengan hal tersebut maka perusahaan dapat memenuhi kebutuhan dana operasionalnya tanpa menggangu keuangan yang lainnya. Riyanto juga menyatakan bahwa semakin tinggi tingkat perputaran kas hal ini menunjukkan semakin efisien tingkat penggunaan kas dalam suatu perusahaan tersebut. hal ini dibuktikan dengan penelitian yang dilakukan oleh Prabasini \& Damayanthi (2019) yang memiliki hasil bahwa tingkat perputaran kas berpengaruh positif dan signifikan pada rentabilitas ekonomi.

Perputaran modal kerja (working capital turnover) merupakan salah satu rasio yang nantinya akan digunakan untuk menilai keefektifan modal kerja suatu perusahaan selama periode tertentu (Kasmir, 2016). Periode perputaran modal kerja perusahaan dimulai dengan kas masuk diiinvestasikan ke komponen-komponen modal kerja sampai dengan menjadi kas kembali (Ritri, 2019). Hasil penelitian dari Prabasini \& Damayanthi (2019) menunjukkan bahwa perputaran modal kerja berpengaruh positif dan signifikan pada rentabilitas ekonomi.

Perputaran Total Aset (total asset turnover) yaitu kemampuan dana yang tertanam dalam keseluruhan aktiva berputar didalam suatu periode tertentu atau kemampuan modal yang diinvestasikan untuk menghasilkan revenue (Sujarweni, 2017). Revenue adalah pendapatan yang didapatkan yang biasanya dapat berupa laba atau profit. Sudrajat (2014) juga melakukan penelitian yang hasilnya adalah Total Assets Turnover (TATO) yang juga berpengaruh signifikan terhadap Rentabilitas Ekonomi.

\section{KAJIAN LITERATUR DAN PENGEMBANGAN HIPOTESIS}

\section{Rentabilitas Ekonomi}

Wahyudiono (2014) berpendapat bahwa rasio rentabilitas ekonomi digunakan dalam mengukur kemampuan aset atau aktiva pada suatu perusahaan untuk memperoleh laba dari operasi perusahaan. Untuk mengukur rasio ini, biasanya dengan laba lalu dibandingkan dengan aktiva perusahaan. Menurut Chairunisa, et al. (2019) rentabilitas ekonomi yaitu kemampuan suatu perusahaan dalam memperoleh laba dengan membandingkan antara laba (sebelum pajak) dengan aktiva yang dimiliki. Jika semakin tinggi rentabilitas ekonomi suatu perusahaan maka semakin tinggi pula laba yang diperolehnya.

Rentabilitas ekonomi mempunyai peran yang penting didalam suatu perusahaan. Hal ini karena bila perusahaan itu mengetahui rentabilitas ekonominya maka dengan itu perusahaan tersebut bisa mengevaluasi apakah pihak manajemen sudah mendapatkan hasil yang sesuai atau belum dengan penggunaan aktivanya yang nantinya dengan hal tersebut dapat mengambil suatu keputusan untuk keberlangsungan kegiatan operasional perusahaan di masa mendatang (Sofiana, et al. 2018). Adapun faktor-faktor yang mempengaruhi rentabilitas ekonomi pada perusahaan antara lain adalah profit margin dan perputaran piutang (Prastowo \& Juliaty, 2010). Octafiani, et al. (2018) berpendapat bahwa rumus yang digunakan untuk mengukur rentabilitas ekonomi suatu perusahaan adalah dengan cara mebandingkan antara laba sebelum pajak dengan total aktiva. 


\section{Perputaran Kas (Cash turnover)}

Gitosudarmo, (2002) menyatakan bahwa tingkat perputaran kas adalah ukuran efisiensi dari penggunaan kas yang dilakukan oleh suatu perusahaan. Rahayu \& Susilowibowo (2014) berpendapat bahwa Perputaran kas yaitu periode berputarnya kas dimulai saat kas diinvestasikan sampai kembali menjadi kas lagi. Rasio perputaran kas ialah perbandingan antara penjualan dengan kas rata-rata. Rasio ini digunakan untuk mengetahui seberapa besar efektivitas suatu perusahaan didalam mengelola kasnya yang nanti akan menghasilkan pendapatan atau penjualan. Angka dari rasio ini semakin tinggi maka akan semakin baik.

Tingkat perputaran kas menunjukkan kecepatan dari arus kas yang ditanamkan di dalam modal kerja yang nantinya menjadi kas kembali. Semakin tinggi tingkat perputaran kas suatu perusahaan maka artinya makin cepat pula kas kembali masuk kepada perusahaan tersebut. Kas yang kembali masuk kepada perusahaan tentunya akan digunakan untuk membiayai kegiatan operasional perusahaan tersebut. Dan nantinya kas tersebut akan kembali lagi ke dalam perusahaan yang berbentuk laba.

Hasil penelitian yang telah dilakukan oleh Rahmasari (2011) menyatakan bahwa perputaran kas berpengaruh positif terhadap rentabilitas ekonomi. Penelitian yang dilakukan oleh Lazaridis, et al. (2006) menyebutkan bahwa perputaran kas berpengaruh positif signifikan terhadap rentabilitas ekonomi. Penelitian yang dilakukan oleh Erlanda (2010) menjelaskan bahwa perputaran kas berpengaruh positif signifikan terhadap rentabilitas ekonomi.

$\mathbf{H}_{1}$ : Cash turnover berpengaruh positif signifikan terhadap rentabilitas ekonomi

\section{Perputaran Modal Kerja (Working capital turnover)}

Bose (2013) berpendapat bahwa perputaran modal kerja adalah aspek yang penting pada keuangan suatu perusahaan yang nantinya akan menggambarkan keefektifitasan penggunaan modal kerja yang dimiliki oleh perusahaan untuk menghasilkan penjualan. Jika perputaran modal kerjanya tinggi maka menandakan bahwa perusahaan tersebut berada dalam posisi yang baik, namun sebaliknya jika perputaran modal kerjanya rendah maka perusahaan tersebut keadaannya kurang baik. Wulandari et al. (2017) menyatakan bahwa Rasio perputaran modal kerja atau working capital turnover adalah salah satu rasio yang dapat mengukur seberapa besarnya perputaran dari modal kerja di suatu perusahaan pada periode tertentu.

Modal kerja pada perusahaan selalu dalam keadaan berputar atau beroperasi pada saat perusahaan tersebut dalam keadaan melakukan aktifitas usahanya. Perputaran modal kerja merupakan faktor penting untuk meningkatkan rentabilitas sebab dengan adanya perputaran modal kerja kas yang diinvestasikan dalam komponen modal kerja dapat meningkatkan laba perusahaan. Laba tersebut dapat diperoleh dari sisi penjualan.

Hasil penelitian Novilia, et al. (2018) menjelaskan bahwa tingkat perputaran modal kerja berpengaruh positif terhadap rentabilitas. Sedangkan hasil penelitian dari Prabasini, et al. (2019) menunjukkan bahwa perputaran modal kerja berpengaruh positif dan signifikan pada rentabilitas ekonomi.

$\mathbf{H}_{\mathbf{2}}$ : Working capital turnover berpengaruh positif signifikan terhadap rentabilitas ekonomi

\section{Perputaran Total Aktiva (Total assets turnover)}

Menurut Yuniningsih (2018:49) perputaran total aktiva digunakan untuk mengukur keefektifan suatu perusahaan dalam penggunaaan total aktiva. Semakin tinggi tingkat perputaran total aktiva maka semakin efektif penggunaannya. Yunita, et al. (2019) berpendapat bahwa perputaran total aktiva adalah rasio yang akan digunakan untuk mengukur intensitas suatu perusahaan dalam penggunaan aktivanya atau 
menunjukkan keefektivitasan dari pihak manajemen perusahaan dalam pengelolaan asetnya untuk memperoleh laba dengan membandingkan antara penjualan dengan rata-rata aset tetap. Total assets turnover merupakan perbandingan antara penjualan dengan total aset atau aktiva dalam suatu perusahaan yang menunjukkan tentang kecepatan dari perputaran total aset dalam periode tertentu (Sya'bani, 2018).

Perputaran total aset memiliki hubungan dengan rentabilitas ekonomi, karena semakin tinggi tingkat perputaran aktiva perusahaan maka menunjukkan bahwa pihak manajemen perusahaan tersebut dapat mengoperasikan aktiva yang digunakan dalam menjalankan kegiatan operasionalnya dengan efisien. Hal tersebut dapat membuat perolehan dari hasil penjualan tahun ke tahun meningkat dan tentunya akan berdampak pada laba yang didapat perusahaan.

Dalam penelitian yang dilakukan Sofiana, et al. (2018) menyatakan bahwa perputaran total aktiva berpengaruh positif dan signifikan terhadap rentabilitas ekonomi. Hasil penelitian Inuzula \& Yuni (2019) menyebutkan bahwa perputaran total aktiva berpengaruh secara positif dan signifikan terhadap rentabilitas ekonomi.

$\mathbf{H}_{3}$ : Total assets turnover berpengaruh positif signifikan terhadap rentabilitas ekonomi

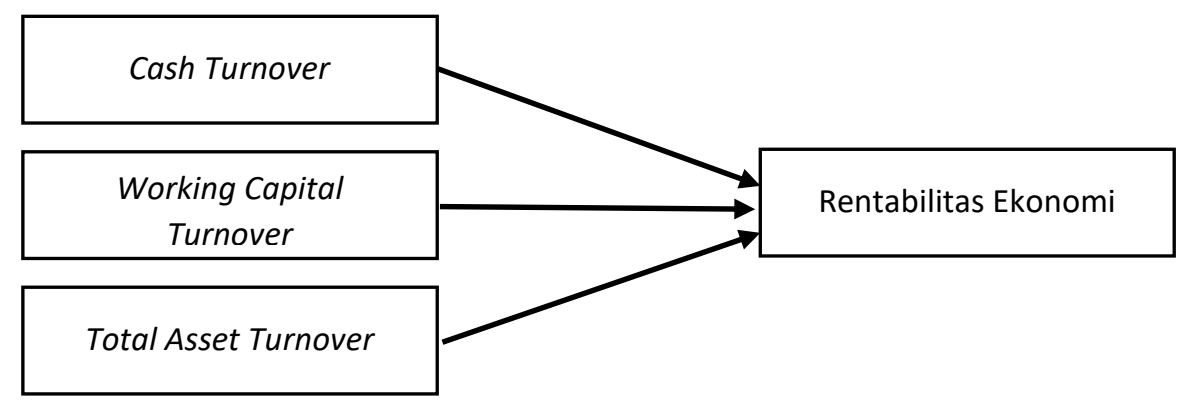

Gambar 1. Model Penelitian

\section{METODE}

\section{Jenis Data}

Jenis data pada penelitian ini menggunakan data kuantitatif. Data kuantitatif adalah data yang diperoleh dalam berbentuk angka dan dapat dihitung dan diukur yang didapatkan dari laporan keuangan objek penelitian. Data yang akan diukur adalah perputaran kas, perputaran modal kerja, perputaran total aset, ukuran perusahaan dan rentabilitas ekonomi.

\section{Sumber Data}

Sumber data didalam penelitian ini adalah data sekunder dimana data tersebut adalah data yang diperoleh secara tidak langsung dari objek penelitian ini. Data dalam penelitian ini didapatkan dari laporan keuangan perusahaan property and real estate yang terdaftar dalam Bursa efek Indonesia mulai dari tahun 2016 sampai dengan tahun 2018 yang diakses melalui www.idx.co.id

\section{Pengumpulan Data}

Metode yang digunakan dalam penelitian ini untuk memperoleh informasi dan juga data adalah menggunakan cara studi pustaka dan juga dokumentasi. Studi pustaka dilakukan dengan melakukan telaah pustaka dari berbagai sumber seperti jurnal, artikel, buku, dan juga berita yang berkaitan dengan topik penelitian ini. Sedangkan Dokumentasi dilakukan dengan cara mengumpulkan data-data yang diperlukan untuk mengerjakan penelitian ini. Dokumentasi juga dilakukan dengan melakukan pencatatan 
mengenai data-data yang terkait. Data yang dimaksud adalah data dari laporan keuangan perusahaan sub sektor property and real estate yang terdaftar dalam Bursa Efek Indonesia delama periode 2016-2018.

\section{Teknik Pengumpulan Sampel}

Objek penelitian ini adalah perusahaan sub sektor property and real estate yang terdaftar di Bursa Efek Indonesia (BEI) selama periode 2016 sampai 2018 yang berjumlah 48 perusahaan. Teknik pengambilan sampel pada penelitian ini yaitu menggunakan purposive sampling, yang artinya bahwa populasi yang dijadikan sampel di penelitian ini merupakan populasi yang memenuhi kriteria sampel tertentu sesuai yang dikehendaki (Singgih, 2001).

\section{Teknik Analisis dan Uji Hipotesis}

Teknik analisis data yang akan digunakan dalam penelitian ini adalah analisis regresi linier berganda yang bertujuan untuk memecahkan masalah secara individual (parsial) dan secara bersama-sama (simultan). Penggunaan teknik analisis ini dilakukan karena penelitian ini bertujuan untuk mengetahui ada atau tidaknya pengaruh antara variabel independen (perputaran kas, perputaran modal kerja, dan perputaran total aset) dengan variabel dependen (rentabilitas ekonomi). Adapun persamaan dari analisis ini, yaitu:

$Y=\alpha+\beta 1 \times 1+\beta 2 \times 2+\beta 3 \times 3+e i$

Dimana :

$Y=$ Rentabilitas Ekonomi

$\mathrm{X} 1$ = Perputaran Kas

X2 = Perputaran Modal Kerja

X3 $=$ Perputaran Total Aset

$\alpha=$ Konstanta

$\beta=$ Koefisien Regresi dari setiap variabel

e $=$ Standar Eror

\section{HASIL DAN PEMBAHASAN}

\section{Uji Parsial (Uji-t)}

Ghazali (2011) berpendapat bahwa Uji t dalam penelitian dilakukan untuk mengetahui seberapa jauh pengaruh satu variabel independen secara individual dalam menjelaskan variasi dari variabel dependen. Uji t dilakukan dengan cara membandingkan nilai statistik atau t dengan titik kritis yang ada di tabel.

Tabel 2. Uji-t

\begin{tabular}{|c|c|c|c|c|c|c|}
\hline & \multirow[b]{2}{*}{ Model } & \multicolumn{2}{|c|}{$\begin{array}{l}\text { Unstandardized } \\
\text { Coefficients }\end{array}$} & \multirow{2}{*}{$\begin{array}{c}\text { Standardized } \\
\text { Coefficients }\end{array}$} & \multirow[b]{2}{*}{$\mathrm{t}$} & \multirow[b]{2}{*}{ Sig. } \\
\hline & & $\mathrm{B}$ & Std. Error & & & \\
\hline \multirow[t]{4}{*}{1} & (Constant) & .727 & .979 & & .743 & .459 \\
\hline & $\mathrm{X} 1$ = Perputaran Kas & -.079 & .116 & -.057 & -.679 & .498 \\
\hline & X2 = Perputaran Modal Kerja & .087 & .142 & .054 & .612 & .542 \\
\hline & X3 = Perputaran Total Assets & 21.330 & 4.752 & .394 & 4.489 & .000 \\
\hline
\end{tabular}

Sumber: Data diolah

Hasil dari Uji T penelitian ini adalah:

1. Perputaran kas berpengaruh negatif tidak signifikan terhadap rentabilitas ekonomi.

2. Perputaran modal kerja berpengaruh positif tidak signifikan terhadap rentabilita ekonomi.

3. Perputaran total aset berpengaruh positif signifikan terhadap rentabilitas ekonomi. 


\section{Uji Simultan (Uji-F)}

Tabel 3. Uji-F

\begin{tabular}{llrrrrr}
\hline Model & & Sum of Squares & Df & Mean Square & F & Sig. \\
\hline 1 & Regression & 549.533 & 3 & 183.178 & 8.289 & $.000^{\mathrm{b}}$ \\
& Residual & 2607.624 & 118 & 22.099 & & \\
& Total & 3157.157 & 121 & & & \\
&
\end{tabular}

a. Dependent Variable: $Y=$ Rentabilitas Ekonomi

b. Predictors: (Constant), X3 = Perputaran Total Assets, $\mathrm{X} 1=$ Perputaran Kas, $\mathrm{X} 2=$ Perputaran Modal Kerja Sumber: Data diolah

Widiyanti dan Bakar (2014) berpendapat bahwa Uji F merupakan uji yang digunakan untuk mengetahui seberapa besar pengaruh dari variabel independen secara bersama-sama terhadap variabel dependen. Hasil dari Uji F pada penelitian ini adalah ketiga variabel Perputaran Kas (X1), Perputaran Modal Kerja (X2), dan Perputaran Total Asset (X3), mampu menjelaskan perubahan variabel Rentabilitas Ekonomi (Y).

\section{Uji $R^{2}$ (Koefisien Determinasi)}

Nawarcono (2011) menyatakan bahwa Koefisien determinasi dalam penelitian digunakan untuk mengetahui besar presentase dari perubahan variabel terikat $(\mathrm{Y})$ oleh variabel bebas $(\mathrm{X})$, atau dengan kata lain koefisien determinasi ialah presentase pengaruh varibel bebas terhadap nilai variabel terikat. Hasil uji koefisien determinasi pada penelitian ni yaitu nilai koefisien determinasi atau R square sebesar 0,174 atau $17,4 \%$. Dari angka tersebut dapat disimpulkan bahwa variabel independen dapat menjelaskan variabel dependen sebesar $17,4 \%$.

Tabel 4. Koefisien Determinasi

\begin{tabular}{|c|c|c|c|c|c|c|c|}
\hline \multirow[b]{2}{*}{ Model } & \multirow[b]{2}{*}{$R$} & \multirow[b]{2}{*}{ R Square } & \multirow[b]{2}{*}{$\begin{array}{l}\text { Adjusted R } \\
\text { Square }\end{array}$} & \multirow[b]{2}{*}{$\begin{array}{c}\text { Std. Error of the } \\
\text { Estimate }\end{array}$} & \multicolumn{2}{|c|}{ Change Statistics } & \multirow[b]{2}{*}{$\begin{array}{l}\text { Durbin- } \\
\text { Watson }\end{array}$} \\
\hline & & & & & $\begin{array}{l}\text { R Square } \\
\text { Change }\end{array}$ & $\begin{array}{c}\text { Sig. F } \\
\text { Change }\end{array}$ & \\
\hline 1 & $.417^{a}$ & .174 & .153 & 4.70091 & .174 & .000 & 2.093 \\
\hline
\end{tabular}

a. Predictors: (Constant), X3 = Perputaran Total Assets, X1 = Perputaran Kas, X2 = Perputaran Modal Kerja

b. Dependent Variable: $Y=$ Rentabilitas Ekonomi

Sumber: Data diolah

\section{Hasil Pembahasan}

Berdasarkan hasil penelitian yang diperoleh, menyatakan bahwa perputaran kas tidak berpengaruh terhadap rentabilitas ekonomi. Artinya hubungan antara perputaran kas dengan rentabilitas ekonomi memiliki hubungan yang berlawanan atau tidak searah. Apabila perputaran kas naik, maka rentabilitas ekonomi akan menurun. Dan apabila perputaran kas menurun, maka rentabilitas ekonomi akan mengalami kenaikan. Adanya hasil hubungan yang tidak signifikan maka dapat diartikan bahwa perputaran kas dalam penelitian ini tidak memiliki kontribusi dalam memperoleh rentabilitas ekonomi perusahaan. Hasil penelitian ini sama dengan hasil penelitian yang telah dilakukan oleh Sufiana dan Purnawati (2011), Rahayu dan Susilowibowo (2014) yang menyatakan jika perputaran kas berpengaruh negatif dan tidak signifikan terhadap rentabilitas. Hal tersebut dapat terjadi karena kas dalam perusahaan digunakan untuk kepentingan lainnya seperti kas digunakan untuk menutupi kerugian yang disebabkan oleh kas digunakan untuk pemeliharaan persediaan yang menumpuk, kas digunakan untuk menutupi piutang-piutang yang tak tertagih, dan kas yang digunakan untuk kepentingan-kepentingan lainnya.

Hasil penelitian menunjukkan bahwa perputaran modal kerja tidak terhadap rentabilitas ekonomi. Hasil tersebut mengartikan bahwa perputaran modal kerja memiliki hubungan yang searah dengan rentabilitas ekonomi. Apabila perputaran modal kerja perusahaan naik, maka akan diikuti oleh rentabilitas ekonomi yang angkanya juga akan naik. Begitupun sebaliknya, jika perputaran modal kerja mengalami penurunan maka angka rentabilitas ekonomi juga akan mengalami penurunan. Perputaran modal kerja berpengaruh 
tidak signifikan terhadap rentabilitas ekonomi yang artinya perputaran modal kerja tidak memiliki kontribusi pengaruh yang besar untuk rentabilitas ekonomi dalam perusahaan tersebut. Hasil dari penelitian ini sama dengan hasil penelitian yang telah dilakukan oleh Karlina, D. (2018) dan Haedar, N. F. (2019) yang sama-sama menyatakan bahwa perputaran modal kerja memiliki hubungan yang positif tidak signifikan terhadap rentabilitas. Tidak adanya pengaruh perputaran modal kerja terhadap rentabilitas ekonomi pada perusahaan property and real estate dapat dikarenakan adanya rendahnya volume dari penjualan dan tingginya hutang yang dimiliki oleh perusahaan-perusahan tersebut. Sehingga karena adanya hal tersebut maka perusahaan property and real estate cenderung menggunakan modal kerja sebagai kebutuhan untuk menutupi hutangnya.

Hasil penelitian yang sudah diperoleh menunjukkan bahwa perputaran total aset berpengaruh positif dan signifikan terhadap rentabilitas ekonomi. Hal tersebut menunjukkan bahwa perputaran total aset memiliki hubungan yang searah dengan rentabilitas ekonomi. Jika perputaran total aset suatu perusahaan naik, maka akan diikuti oleh rentabilitas ekonomi yang nilainya juga akan naik. Dan sebaliknya, jika perputaran total aset menurun maka nilai dari rentabilitas ekonomi juga akan menurun. Perputaran total aset memiliki kontribusi yang besar untuk meningkatkan rentabilitas ekonomi. Hasil menunjukkan jika aset yang dimiliki oleh suatu perusahaan banyak, maka jumlah dari penjualan dapat ditingkatkan lebih tinggi. Semakin tinggi nilai penjualan maka semakin tinggi laba yang akan dimiliki oleh perusahaan. Perputaran total aset memiliki kontribusi yang besar dalam perusahaan untuk memperoleh laba.

\section{SIMPULAN}

Perputaran kas tidak berpengaruh terhadap rentabilitas ekonomi pada perusahaan property and real estate dan komponennya di BEl. Yang artinya perputaran kas mempunyai hubungan yang berlawanan arah dengan rentabilitas ekonomi dan perputaran kas memberikan kontribusi yang kecil atau mungkin tidak memberikan kontribusi sama sekali terhadap rentabilitas ekonomi.

Perputaran modal kerja tidak berpengaruh terhadap rentabilitas ekonomi pada perusahaan property and real estate dan komponennya di BEI. Yang artinya perputaran modal kerja mempunyai hubungan yang searah dengan rentabilitas ekonomi namun perputaran modal kerja memberikan kontribusi yang kecil atau bahkan tidak memberikan kontribusis sama sekali terhadap rentabilitas ekonomi.

Perputaran total aset berpengaruh positif signifikan terhadap rentabilitas ekonomi pada perusahaan property and real estate dan komponennya di BEI. Yang artinya perputaran total aset mempunyai hubungan yang searah dengan rentabilitas ekonomi dan perputaran total aset mempunyai kontribusi yang besar terhadap rentabilitas ekonomi.

Perputaran kas, perputaran modal kerja dan perputaran total aset mampu menjelaskan rentabilitas ekonomi yang ada pada perusahaan property and real estate. Yang artinya ketiga variabel tersebut secara bersama-sama mempunyai pengaruh yang signifikan terhadap rentabilitas ekonomi.

\section{REFERENSI}

Aji, S. S. (2019). Perkembangan Kinerja Keuangan PT. Indofood Sukses Mamkmur Tbk pada Periode 20122016. Jurnal Ekobis Dewantara, 1(12), 189-210.

Bambang Wahyudiono, S. E., \& MM, Q. (2014). Mudah Membaca Laporan Keuangan. RAIH ASA SUKSES.

Bose, B. (2013). The impact of working capital management practices on firm's profitability. International Journal of Applied Research and Studies, 2(6), 1-15.

Cipta, C. (2019). Rentabilitas Ekonomi PD. BPR PK Arahan: Pengaruh Hutang Terhadap Kredit. Jurnal Investasi, 5(1), 38-58. 
Erlanda, T. (2010). Analisis efisien modal kerja dan pengaruhnya terhadap rentabilitas ekonomi pada pusat koperasi pegawai Republik Indonesia (PKP-RI) Propinsi Sumatra Barat. Skripsi. Universitas Andalas.

Ghozali, I. (2006). Aplikasi analisis multivariate dengan program SPSS. Badan Penerbit Universitas Diponegoro.

Ghozali, I. (2011). Aplikasi analisis multivariate dengan program SPSS. Badan Penerbit Universitas Diponegoro.

Gitosudarmo, I. (2002). Manajemen Keuangan. Yogyakarta: BPFE.

Haedar, N. F. (2019). Pengaruh perputaran modal kerja terhadap profitbilitas pada PT. Waskita Karya (Persero) Tbk di Bursa Efek Indonesia (BEI). Jurnal Manajemen Keuangan. Skripsi. Fakultas Ekomomi Universitas Negeri Makassar.

Husnan, S, \& Pudjiastuti, E. (2004). Dasar-Dasar Manajemen Keuangan, edisi empat. Yogyakarta: UPP AMP YKPN.

Inuzula, L. (2019). Pengaruh Perputaran Total Aktiva, Persediaan Dan Piutang Terhadap Rentabilitas Ekonomi Pada Pt. Mayora Indah Tbk Periode 2011-2016. Akbis: Media Riset Akuntansi dan Bisnis, 2(2).

Karlina, D. (2018). Pengaruh Leverage, Perputaran Modal Kerja, Perputaran Persediaan, Risiko Bisnis Dan Siklus Konversi Kas Terhadap Profitabilitas. Skripsi. Universitas Lampung Bandar Lampung.

Kasmir. (2016). Analisis Laporan Keuangan. Cetakan kesembilan. Jakarta : PT. Raja Grafindo Persada

Lazaridis, I., \& Tryfonidis, D. (2006). Relationship between working capital management and profitability of listed companies in the Athens stock exchange. Journal of financial management and analysis, 19(1), 26-35.

Menuh, N. N. (2008). Pengaruh Efektivitas dan Efisiensi Penggunaan Modal Kerja Terhadap Rentabilitas Ekonomi Pada Koperasi Pegawai Negeri Kamadhuk RSUP Sanglah Denpasar. In Jurnal Forum Manajemen (Vol. 6, No. 1, pp. 86-96).

Munawir, (2002). Analisa Laporan Keuangan. Edisi kedua. Yogyakarta: YKPN.

Nawarcono, W. (2011). Pengaruh Tingkat Perputaran Piutang, Persediaan Dan Modal Kerja Terhadap Rentabilitas Ekonomi (Studi Kasus: Perusahaan Manufaktur Yang Terdaftar Di Bei Tahun 20072009). Jurnal Ekonomi dan Kewirausahaan, 7(14).

Prabasini, K. S. G., \& Damayanthi, I. G. A. E. (2019). Pengaruh Tingkat Perputaran Modal Kerja, Leverage, Tingkat Perputaran Kas, dan Pertumbuhan Perusahaan Pada Rentabilitas Ekonomi. E-Jurnal Akuntansi, 27(1), 737-763.

Prastowo, D., \& Juliaty, R. (2010). Analisis Laporan Keuangan. Edisi ketiga. Jakarta: Unit penerbit dan percetakan akademi manajemen perusahaan YKPN.

Pratiwi, N. J. E., Tiara, S., \& Dewi, R. S. (2018). Pengaruh Efisiensi Pengendalian Biaya dan Tingkat Perputaran Modal Kerja terhadap Rentabilitas pada Perum Damri Cabang Medan. Jurnal Akuntansi dan Pembelajaran, 7(2).

Rahayu, E. A. (2014). Pengaruh Perputaran Kas, Perputaran Piutang Dan Perputaran Persediaan Terhadap Profitabilitas Perusahaan Manufaktur. Jurnal IImu Manajemen (Jim), 2(4).

Rengkung, L. R., \& Pangemanan, L. R. (2019). Rentabilitas Perusahaan Agribisnis di Bursa Efek Indonesia (BEI). Agri-Sosioekonomi, 14(3), 239-246.

Riyanto, B. (2011). Dasar-Dasar Pembelanjaan Perusahaan. Edisi keempat. Yogyakarta: BPFE 
Sofiana, S., Oemar, A., \& Santoso, E. B. (2018). Pengaruh Perputaran Piutang, TaTo, Cash Turnover dan Modal Kerja Terhadap Rentabilitas Ekonomi Dengan Profit Margin Sebagai Variabel Intervening (Pada Perusahaan Manufaktur yang terdaftar Di Bursa Efek Indonesia Tahun 2012-2016). Journal Of Accounting, 4(4).

Sujarweni, W. V. (2017). Analisis Laporan Keuangan. Yogyakarta: Pustaka Baru Press

Widiyanti, M., \& Bakar, S. W. (2014). Pengaruh working capital turnover, cash turnover, inventory turnover dan current ratio terhadap profitabilitas (roa) perusahaan property dan real estate yang terdaftar di bei. Jurnal manajemen dan bisnis sriwijaya, 12(2), 111-126.

Wijaya, T. (2012). Cepat Menguasai SPSS 20 untuk Olah dan Interpretasi Data. Yogyakarta: Cahaya Atma Pustaka.

Wulandari, I., Oemar, A., \& Hartono, H. (2017). Pengaruh perputaran modal kerja, perputaran asset tetap, perputaran piutang, Perputaran Kas dan perputaran persediaan terhadap Net Profit Margin (NPM) pada Peru sahaan Manufaktur di Bursa Efek Indonesia periode 2011-2015. Journal Of Accounting, 3(3).

Yuniningsih. (2018). Dasar-Dasar Manajemen Keuangan. Edisi pertama. Sidoarjo: Indomedia pustaka.

Yunita, Y., Shelly, S., Ariani, N., Chandra, E., Selvia, S., Pane, A., \& Putra, S. K. (2019). Pengaruh Times Interest Earned Ratio, Total Asset Turnover dan Perputaran Modal Kerja terhadap Profitabilitas pada Perusahaan Sub Sektor Property dan Real Estate yang terdaftar di Bursa Efek Indonesia periode 2013-2017. Jesya (Jurnal Ekonomi dan Ekonomi Syariah), 2(2), 253-264. 